ROCZNIKI PEDAGOGICZNE

Tom 12(48), numer $1-2020$

DOI: http://dx.doi.org/10.18290/rped20121-8

IWONA SZEWCZAK

\title{
W TROSCE O ARETOLOGICZNE PODSTAWY WYCHOWANIA. WOKÓŁ KONCEPCJI O. JACKA WORONIECKIEGO
}

\section{WPROWADZENIE}

Współcześnie obserwujemy kryzys wychowania. Wśród najważniejszych zagrożeń, z jakimi muszą mierzyć się wychowawcy, należy wymienić wszechobecną przestrzeń wirtualną, która zakłóca czy uniemożliwia budowanie rzeczywistych relacji interpersonalnych, uzależnienia od alkoholu, narkotyków, agresję, przemoc, często powiązane z nurtami kulturowymi inspirowanymi relatywizmem, hedonizmem, pluralizmem, wolnością, indywidualizmem czy chwiejnością światopoglądową. Pedagodzy podejmują refleksję nad tym, jak powinno wyglądać wychowanie, które byłoby w stanie sprostać wymaganiom współczesnego świata. Możliwości rozwiązania przedmiotowego kryzysu upatrują między innymi w konieczności pogłębiania fundamentalnych zagadnień antropologiczno-aksjologicznych, a także w rozpoznaniu sytuacji życia człowieka w wymiarach społecznym, politycznym i ekonomicznym.

Przy określaniu podstaw aksjologicznych wychowania akcentuje się obecnie potrzebę powrotu do wartościowań typu arystotelesowskiego. K. Śleziński zauważa, że z tą tendencją mamy do czynienia od lat siedemdziesiątych ubiegłego wieku, a przejawia się ona wyraźnym ożywieniem wokół problematyki cnót (Śleziński, 2016). I chociaż kwestiom aksjologicznym poświęca się w ostatnich latach więcej uwagi niż kilkadziesiąt i kilkanaście lat temu, analizując wartości, ich źródło, naturę, treści, poszukiwanie wartości uniwersalnych silnie zakorzenionych w tradycji humanistycznej, eksponujących kwestie godnego życia, podmiotowości, praw człowieka, wciąż

Dr Iwona SzewCZAK - Katedra Pedagogiki Chrześcijańskiej, Instytut Pedagogiki Katolickiego Uniwersytetu Lubelskiego Jana Pawła II, adres do korespondencji: Al. Racławickie 14, 20-950 Lublin; e-mail: iwona.szewczak@kul.pl; ORCID: https://orcid.org/0000-0001-9940-458X. 
zauważa się brak pogłębionego odniesienia do dążenia osoby do wartości (Nowak, Magier, Szewczak, 2010) oraz wystarczającego bezpośredniego odwołania do teorii cnót. Współcześnie wychowanie do wartości czy wychowanie $\mathrm{w}$ wartościach wiąże się często ze stanowiskiem intelektualizmu moralnego wypracowanego $\mathrm{w}$ dobie oświecenia, w którym podkreśla się fundamentalne znaczenie wychowania rozumu bez uwzględnienia wychowania woli. Wychowania do wartości nie można ograniczyć jedynie do przedstawienia wartości, równie ważna jest kondycja moralna wychowanka.

Istnieje zatem $\mathrm{w}$ pedagogice potrzeba zwrócenia się $\mathrm{w}$ kierunku normatywności, dotyczącej zmierzania do wartości i do cnót oraz ich osiągania przez człowieka.

Wydaje się, że przywrócenie właściwej rangi dobru i cnotom stanowi jedną z możliwości przezwyciężenia współczesnego kryzysu wychowania. Etyka klasyczna, nawiązująca do myśli Arystotelesa i Tomasza z Akwinu, dostarczając racjonalnych podstaw oparcia zjawisk kulturowych na aretologii oraz określając miejsce moralności w życiu ludzkim i pedagogice, może stanowić swoiste antidotum na współczesny kryzys wychowania.

Jedną z propozycji oparcia wychowania na aretologii jest koncepcja o. Jacka Woronieckiego, nabudowana na filozofii Tomasza z Akwinu.

\section{WYCHOWANIE W UJECIU O. WORONIECKIEGO}

Koncepcja wychowania o. Jacka Woronieckiego osadzona jest na realizmie ontologicznym i teoriopoznawczym w głoszeniu konieczności integralnego wychowania i kształcenia człowieka. Podstawą koncepcji wychowania jest realistyczna antropologia, według której człowiek jest jednością duszy i ciała. Władze cielesne i duchowe podlegają jednak hierarchizacji. Sfery wegetatywna i zmysłowa są podporządkowane władzom intelektualnym. Rozum i wola jako dwie naczelne władze człowieka decydują o jego działaniach, muszą jednak współpracować z innymi elementami ludzkiej natury (Woroniecki, 1995). „Żadne z jestestw znanego nam świata nie jest tak plastyczne i zdolne do rozwoju jak człowiek: potencjalność jest naczelnym prawem, które nim rządzi i z zewnątrz i z wewnątrz" (Woroniecki, 1995, s. 191). Potencjalność jest cechą najbardziej charakterystyczną natury ludzkiej. Przymiot ten nie pozwala człowiekowi nie rozwijać się, oznacza możliwość i konieczność rozwoju. Możliwości są „dane” człowiekowi, człowiek nie ma na nie wpływu, ale nie determinują one jego rozwoju. Podmiot 
tych potencjalności jest bytem suwerennym, podejmuje autonomiczną decyzję o tym, które z nich i w jaki sposób będzie aktualizować. Proces wychowania może przynieść realne skutki, gdy wychowanek wyrazi na nie zgodę, zaakceptuje cnoty, do których ma dążyć. Samowychowanie jest więc nie tylko koniecznym warunkiem wychowania, ale też jego celem. Aktywność własna wychowanków jest niezbędna, a wychowawca ma pobudzać do zachowań zgodnych z oczekiwaniami społecznymi i zasadami moralności (Brezinka, 1981). W ostateczności chodzi przecież o przejęcie przez wychowanka kierownictwa nad własnym rozwojem w jego dojrzałości i samodzielności. W gruncie rzeczy wszelkie wychowanie jest samowychowaniem, a akty zewnętrzne wobec niego, w tym działalność wychowawcy, mają charakter pomocniczy (Woroniecki, 1961).

Człowiek jest jednak bytem przygodnym, niesamodzielnym, co oznacza, że w swoim istnieniu oraz realizowaniu potencjalności potrzebuje współdziałania z zewnątrz: przede wszystkim Boga, ale też innych osób, całego społeczeństwa. Fakt ten naprowadza na problematykę wychowania.

Wychowanie w ujęciu o. Woronieckiego polega na „przyzwyczajaniu się lub na nawykaniu do dobrego" (Woroniecki, 1961, s. 33). Konieczne do wyjaśnienia fenomenu wychowania jest określenie cnoty - czynnika uniesprzeczniającego wychowanie. Istotną cechą tego procesu - zjawiska jest ukierunkowanie na przyszłość. Wychowawca podejmuje działanie ze względu na „dobro rozwojowe człowieka nie aktualnie pojęte, ale realizujące się w przyszłości, nastawione ku przyszłości, dzięki czemu człowiek może się w pełni doskonalić i osiągnąć kres procesu rozwoju" (Kunowski, 2001, s. 39). Formowanie sprawności będzie więc zawsze istotą procesu wychowawczego. Jak zaznacza S. Gałkowski, rezygnacja z pomocy w uzyskaniu przez wychowanka pewnych usprawnień przydatnych mu w przyszłym życiu byłaby rezygnacją z wychowania (Gałkowski, 1998). Celem wychowania jest nakierowanie wychowanka na spełnianie dobrych czynów. Środkiem do osiągnięcia takiego celu jest przede wszystkim czyn, nie słowo. Nie wystarczy instruować dziecko, jak ma postępować, należy stworzyć mu warunki, w których będzie miało możliwość doświadczania czynów dobrych moralnie, przez co będzie się do tych czynów zaprawiało. Wychowanie powinno obejmować całego człowieka, wszystkie jego władze, zarówno fizyczne, jak i umysłowe. Oddziaływanie na ludzkie zmysły ma na celu wpływ na władze czysto duchowej natury: rozum i wolę, ale również niższe, bardziej związane z ciałem pożądania zmysłowe, wyobraźnię i emocje. 
Celem wychowania jest osiągnięcie przez wychowanka pełni bytu ludzkiego, możliwie najpełniejsze rozwinięcie świadomości i wolności, czyli zdolności do samodeterminacji własnych aktów (Woroniecki, 1961). Odbywa się to w procesie nabywania sprawności, czyli cnót.

\section{KONCEPCJA CNOTY O. JACKA WORONIECKIEGO}

Cnotą w ujęciu dominikanina jest sprawność moralna, czyli usprawnienie do czynu władz pożądawczych, zarówno zmysłowych - uczuć, jak i umysłowych - woli. Cnota oznacza sprawność moralnie dodatnią, w odróżnieniu od sprawności moralnych ujemnych, czyli wad (Woroniecki, 1995). Dominikanin używa zamiennie wyrażeń „cnota” i „sprawność”, co jak zaznacza S. Gałkowski, jest dopuszczalne, ponieważ pojęcie wychowania o. Woroniecki utożsamia $\mathrm{z}$ wychowaniem moralnym, w tej dziedzinie zaś pojęcia cnoty i sprawności pokrywają się (Gałkowski, 1998).

Przez sprawności dokonuje się integracja osoby w czynie, który jest tym, co integruje wszystkie funkcje człowieka. Sprawność, dzięki której postępowanie człowieka nie tylko odpowiada wymogom moralności, ale jest przynajmniej w pewnych warunkach życia wolne od wahań i wewnętrznych zmagań, należy odróżnić od nawyku czy wyuczonego odruchu. Nawyk jest czynnością automatyczną, wynikiem wielokrotnego, mechanicznego jej powtarzania. Człowiek dokonuje go zupełnie lub częściowo nieświadomie, bez udziału wolnej woli. Czynność taka jest zatem moralnie obojętna. W spełnianiu czynów wynikających $\mathrm{z}$ cnoty bierze udział świadomość i wola, pojawia się element podejmowania decyzji. Sprawność nabywa się poprzez ćwiczenia, których celem jest wyrobienie trwałych dyspozycji, a nie zmechanizowanie czynności. Cnota - sprawność jest skondensowanym doświadczeniem, dzięki któremu człowiek może bez wahań i długotrwałych poszukiwań dojść do postanowienia najlepiej odpowiadającemu celowi i warunkom, w jakich ma być osiągnięte (Woroniecki, 1995). Działanie ludzkie powinno być zgodne z sumieniem oraz sprawne, czyli szybkie, efektywne i angażujące jedynie tyle wysiłku, ile jest to koniczne.

Zakres sprawności człowieka jest równoznaczny z zakresem wpływu woli i rozumu. „Wszystko to, co w nas może być świadomym naszym aktem w czyn wprowadzone, może też być przedmiotem usprawnienia w odnośnej władzy" (Woroniecki, 1995, s. 337). Przedmiotem sprawności mogą być akty zewnętrzne (sprawności fizyczne) oraz funkcje umysłowe rozumu i woli 
(cnoty intelektualne i cnoty moralne). W dziedziny te wpisana jest potencjalność, dlatego podlegają rozwojowi, czyli usprawnieniom. Sprawności różnią się w zależności od władzy ludzkiej, której dotyczą. Ojciec Woroniecki wyodrębnia trzy grupy usprawnień: sprawności z dziedziny życia fizjologicznego, cnoty poznawcze, a wśród nich cnoty intelektualne (w wymiarze teoretycznym) oraz cnoty techniczne (w dziale praktycznym), oraz sprawności moralne - wady i cnoty (Woroniecki, 1995). Warto podkreślić, że cnota ma charakter relacjonalny, przejawia się różnie w zależności od indywidualnych możliwości oraz pełnionych przez człowieka funkcji.

Dominikanin, zakładając, że usprawnienia dotyczą całości moralnego życia człowieka, konstruuje system cnót, który obejmuje wszystkie władze ludzkie. Łączy w jeden system cnoty kardynalne, opracowane przez Platona, oraz cnoty teologiczne. Poszczególnym władzom człowieka odpowiadają usprawniające je cnoty kardynalne. I tak zadaniem roztropności jest usprawnienie rozumu w postępowaniu, usprawnieniem woli zajmuje się sprawiedliwość, męstwo doskonali uczucia popędliwo-bojowe, a umiarkowanie zajmuje się uczuciami pożądliwymi (Woroniecki, 1983).

\section{CNOTY KARDYNALNE}

\section{JAKO NATURALNE ŚRODKI ROZWOJU CZŁOWIECZEŃSTWA}

Cnoty kardynalne są podstawowymi cnotami moralnymi, stanowiącymi jednocześnie cele wychowania. Nazywa się je kardynalnymi, przyrównując do zawiasów, na których opiera się cała działalność moralna człowieka. Ojciec Woroniecki podkreśla, że sprawności pozytywne, czyli cnoty, są możliwe jedynie wówczas, gdy dobrze działają wszystkie władze człowieka (Woroniecki, 1995).

\section{Roztropność - usprawnieniem rozumu w postępowaniu}

Roztropność jest usprawnieniem rozumu praktycznego, w którym o. Woroniecki, idąc za koncepcją cnót Arystotelesa i św. Tomasza, wyodrębnił trzy czynności: namysł, rozmysł i nakaz. Dokładna analiza procesu podejmowania decyzji przez człowieka doprowadziła dominikanina do stwierdzenia, że roztropność nie jest możliwa bez rozwagi i rozsądku, dwóch cnót pokrewnych roztropności. Sama odnosi się do nakazu, który zostaje wydany woli przez rozum, co skutkuje konkretnym działaniem, jednak rozkaz musi być poprzedzony namysłem nad środkami umożliwiającymi osiągnięcie celu oraz rozmysłem wyboru środka najwłaściwszego w danej sytuacji. Do sprawnego 
funkcjonowania rozumu praktycznego nieodzowna jest wola, która pozwala człowiekowi zachować umiar, zwłaszcza w życiu moralnym.

Cnota roztropności oddziałuje na wszystkie inne cnoty moralne w obszarze zachowywania umiaru i kierowania w wyborze środków do realizacji celów (Woroniecki, 1986; Kempys, 2005).

Ojciec Woroniecki wyodrębnił dwa rodzaje roztropności: osobistą, która stanowi punkt wyjścia do życia moralnego, oraz społeczną. Człowiek, będąc istotą społeczną, musi odnosić swe postępowanie do potrzeb ogólnego dobra całego społeczeństwa, w którym żyje (Woroniecki, 1923). Roztropnością społeczną powinni kierować się przełożeni, u których przedmiotowa cnota winna stanowić kardynalny warunek właściwego wypełniania obowiązku rządzenia, a także rodzice i wychowawcy, u których cnota roztropności wiąże się ze szczególnymi zadaniami rodzinnymi - wydaniem potomstwa i jego dobrym wychowaniem oraz aktywnym udziałem w życiu społeczności lokalnej i narodowej. Innymi rodzajami roztropności społecznej wyodrębnionymi przez Woronieckiego są: roztropność wojskowa oraz zawodowa. Pierwsza z nich powinna odznaczać się szybkością orientowania się w sytuacji, zapobiegliwością, przytomnością umysłu, stanowczością. Druga związana jest z zasadami i regułami postępowania, charakterystycznymi dla poszczególnych grup zawodowych (Woroniecki, 1986). Wpisuje się w etos zawodowy. Dominikanin konstatuje, że roztropny i uczciwy pracownik powinien poznać swe obowiązki i wzbogacić je własnym doświadczeniem, ale jego osobista roztropność musi zostać też ubogacona roztropnością zawodową. Woroniecki wskazuje na jeszcze jeden rodzaj przedmiotowej cnoty - roztropność nadprzyrodzoną, która rozwija się pod wpływem cnót boskich - wiary, nadziei i miłości. Dopiero miłość gwarantuje wszystkim cnotom życia moralnego pełnię rozwoju.

Roztropność jako cnota porządkująca liczne obszary ludzkiego życia ma złożoną budowę. Składa się na nią siedem cnót intelektualnych: pamięć, która porządkuje doświadczenia z przeszłości; pojętność, zwana zmysłem rzeczywistości, czyli zdolność rozumu do zbierania materiału; następnie gotowość przyjęcia rad i pouczeń; domyślność, czyli zmysł obserwacyjny, a także zdrowy sąd - bystrość, oznaczająca umiejętność prawidłowego rozumowania i dokonania właściwego wyboru. W fazie roztropnego działania niezbędny jest kolejny składnik cnoty - przezorność, czyli zdolność przewidywania. Kolejnymi składnikami przedmiotowej sprawności są oględność, oznaczająca zdolność zmiany planu postępowania w zależności od nowych okoliczności oraz zapobiegliwość, czyli zdolność przewidywania trudności 
i przeszkód w realizacji zamierzonego planu oraz skutecznego im zapobiegania (Woroniecki, 1986). Innymi składnikami roztropności, pozwalającymi człowiekowi na osiągnięcie doskonałości w dziedzinie działania moralnego, na które wskazuje dominikanin, są cnota prawości, rozumiana jako pragnienie dążenia do tego, co jest prawdziwym dobrem, związana z nią szczerość, a także cnota pilności oznaczająca pewne napięcie woli, aby zawsze należycie przykładać się do tego, co się czyni. Woroniecki wskazuje również na cnoty obowiązkowości, sumienności oraz stałości woli, która oznacza stałe i równomierne kierowanie woli do obranego celu. Innymi składnikami roztropności są stanowczość, regularność i punktualność. Spośród wad o treści przeciwstawnej roztropności omawianych przez dominikanina na szczególną uwagę zasługują wady powstałe z braku pilności: niezdecydowanie oraz niestałość, która oznacza chwiejność, brak stanowczości i decyzji. Wady te charakteryzują współczesnych młodych ludzi, którzy, bojąc się odpowiedzialności, nie podejmują decyzji dotyczących ważnych życiowych kwestii, jak np. małżeństwa, wyboru zawodu, lub odkładają je w czasie (Woroniecki, 1986).

Wychowanie do roztropności, ze względu na złożoność tej cnoty, jest zadaniem trudnym i skomplikowanym. Polega na systematycznym rozwijaniu i ćwiczeniu wrodzonych czynników zmysłowych i duchowych człowieka oraz nadaniu im cech roztropności. Wychowawca powinien ukierunkować swoje działania na rozum i wolę wychowanka. Już od wczesnych lat życia dziecka powinien rozwijać jego pamięć poprzez troskę, by nie zapominało swoich przeżyć, a wyciągało z nich wnioski. Woroniecki zaznacza, że częste zapominanie nie może być usprawiedliwiane i należy traktować je jako niedbalstwo (Woroniecki, 1923). Istotne - szczególnie współcześnie w dobie społeczeństwa informacyjnego i społeczeństwa nowoczesnych mass mediów, w którym zacierają się różnice pomiędzy światami rzeczywistym a wirtualnym, mającymi zupełnie inną naturę ontologiczną - jest kształtowanie realnego stosunku do rzeczywistości, który dominikanin nazywa pojętnością. Dużą wagę należy przywiązywać do samodzielności wychowanka, a drogą do niej jest korzystanie z doświadczenia innych, jednak nie bezkrytyczne. Woroniecki zaleca ćwiczyć spostrzegawczość dziecka, czyli umiejętne patrzenie na świat i ludzi i sprawne rozumowanie o tym, co uzyskuje dzięki własnej obserwacji, dobrej lekturze, rozmowom. Wychowawca winien powstrzymywać wychowanków przed zbyt szybkim, niejednokrotnie lekkomyślnym podejmowaniem decyzji, $z$ drugiej strony zachęcać tych powolniejszych, chwiejnych do intensywnego myślenia i działania oraz czuwać nad sprawną, czyli przezorną co do okoliczności i zapobiegliwą wobec przeszkód, realizacją postanowień. 
Wychowanie woli ma polegać na stałym i równomiernym przykładaniu się do wszelkiego rodzaju czynności. Umacnianie woli to przede wszystkim kształtowanie jej prawości, czyli życia w prawdzie. Szczerość intencji i pilność woli powinna charakteryzować działanie wychowanków tak, aby każde podejmowane przez nich przedsięwzięcie poprzedzone było starannym obmyśleniem koniecznych do osiągnięcia celu środków. Woroniecki zaleca ćwiczenie pilności i dbałości u dzieci poprzez kaligrafię. Istotne jest kształtowanie odpowiedniego stosunku do obowiązków i sumienne, regularne i punktualne ich wykonywanie (Woroniecki, 1986; Kempys, 2005).

Roztropność będzie przydatna w kontaktach międzyludzkich jedynie wtedy, gdy człowiek będzie uwzględniał wolę innych ludzi. Kolejnym zatem zadaniem człowieka roztropnego jest nabycie cnoty sprawiedliwości.

\section{Sprawiedliwość jako usprawnienie woli}

Sprawiedliwość uważana jest za pierwszą cnotę społeczną i kardynalną. Aby jednak była pełna, cnota musi być głęboko ugruntowana w woli. Wola jako władza czysto duchowa jest prosta i nie da się jej rozłożyć na poszczególne składniki, można jednak wyodrębnić podstawowe czynności w stosunku do własnego przedmiotu. W przypadku sprawiedliwości jest to zasada: „unikaj zła, a czyń dobro”, która odnosi się do relacji międzyludzkich. Ojciec Woroniecki wskazuje na trzy typy tych relacji: jednostka a społeczeństwo, jednostka a jednostka oraz społeczeństwo a jednostka, przyporządkowując każdemu z nich inny rodzaj sprawiedliwości. Pierwszy - sprawiedliwość współdzielcza, zwana cnotą praworządności, oznacza stałą chęć życia w ładzie społecznym oraz współdziałaniu w zaprowadzaniu go, podtrzymywaniu i rozwijaniu. Chodzi o ustosunkowanie woli do całokształtu prawa, porządku, spokoju, bezpieczeństwa, czyli dobrobytu społecznego, od którego zależy dobrobyt osobisty obywateli. Drugim składnikiem sprawiedliwości jest sprawiedliwość wymienna, zwana również cnotą uczciwości. Bazuje na równości, czyli ścisłym wymierzaniu, co się komu należy, i takim podziale dóbr, aby obie jednostki otrzymały równowartość tego, co wniosły. Wyznacznikami uczciwości są przykładowo dostarczenie odpowiedniego towaru, zapłacenie umówionej ceny, sumienne płacenie podatków, spłacanie długów, czy dyskrecja. Trzeci rodzaj - sprawiedliwość rozdzielcza zwany jest cnotą równomierności. Jej rola polega na wprowadzaniu umiaru w podziale dóbr i ciężarów życia społecznego oraz udziału wszystkich obywateli we wspólnym dobrobycie. Woroniecki wyodrębnia trzy cnoty równomierności: umiejętność rozdzielenia tego, co jest wspólne, gotowość zadowolenia się mniejszym udziałem w dobrach wspólnych oraz uznanie, że inni mają większe 
potrzeby oraz umiejętność użytkowania majątku i wydawania pieniędzy z pożytkiem dla innych.

Wśród cnót pokrewnych sprawiedliwości, które problematyzuje dominikanin, warto zwrócić uwagę na cześć wobec rodziców, wyrażającą się między innymi w posłuszeństwie, oraz szacunek wobec innych, przejawiający się delikatnością i poszanowaniem życia. Ważnym zadaniem dla wychowawców jest dziś również wychowanie do wdzięczności, która zakłada pokorę, oraz prostoty, czyli zgodności myśli, mowy i działania człowieka. Istotna, szczególnie współcześnie w dobie rozpowszechnionego indywidualizmu, jest wpisująca się w miłosierdzie cnota dobroczynności, którą o. Woroniecki rozpatruje nie tylko w wymiarze materialnym, ale przede wszystkim duchowym. Aktami dobroczynności: są cierpliwe wysłuchanie skarg, okazywane współczucie czy przyjmowanie niewdzięczności od tych, którym kiedyś udzieliło się pomocy (Woroniecki, 1986).

Właściwe pojmowanie cnoty sprawiedliwości i jej nabycie może być receptą na współcześnie obserwowane fenomeny niewrażliwości na potrzeby innych, zazdrości, usiłowanie wykorzystywania innych, dążenie do zrównania $\mathrm{z}$ innymi w otrzymywaniu dóbr bez uwzględnienia indywidualnej sytuacji każdego z członków społeczeństwa. Podstawowym środowiskiem kształtowania przedmiotowej cnoty powinna być rodzina, a następnie szkoła. Uświadomienie wad o treści przeciwstawnej sprawiedliwości - takich jak pycha, próżność, arogancja, skąpstwo, zazdrość i zawiść, chciwość, faworyzowanie, służalczość, pobłażliwość czy samowola - pomaga wychowawcom we wspieraniu nabywania sprawiedliwości przez ich wychowanków.

\section{Męstwo - doskonaleniem uczuć popędliwo-bojowych}

Kardynalna cnota męstwa oznacza moc i wytrzymałość wobec trudności, towarzyszących złu, którego człowiek pragnie uniknąć, lub dobru, które pragnie zdobyć. Męstwo staje się składowym czynnikiem charakteru człowieka, gdy władze zmysłowe, działające początkowo samorzutnie, nabierają stałych sprawności do współpracy z rozumem i wolą. W przedmiotowej cnocie wyróżnia się dwa czynniki. Pierwszy z nich, niecofanie się wobec grożącego zła - skutkuje zaufaniem we własne siły, drugi, atakowanie zła przyczynia się do powstania poczucia bezpieczeństwa. W zależności od okoliczności rozum wskazuje właściwe rozwiązanie, atak bądź wycofanie się. Aby uczucia, które towarzyszą męstwu - takie jak strach i śmiałość, gniew, zniechęcenie, otucha i zadowolenie - zyskały wartość moralną, należy wprowadzić między nimi porządek. Przykładowo sama wrodzona śmiałość czy odwaga nie jest jeszcze cnotą ani męstwem. Dzięki męstwu zyskuje ona 
cechę czynności rozumnej, w dostosowaniu siły zmysłowej do określonego celu. Odwaga pozbawiona pierwiastka rozumu nigdy nie stanie się męstwem (Woroniecki, 1938).

Jacek Woroniecki wskazuje na sześć cnót pokrewnych kardynalnej cnocie męstwa, których zadanie polega na przygotowaniu podłoża dla jego ukształtowania lub jego wzmocnienie. Pierwszą z nich jest cierpliwość. Nosi ona w sobie piętno pewnej mocy i hartu ducha, czyli wewnętrznego nastroju woli, który jest dowodem panowania nad mogącymi się pojawić w realizacji zamierzeń zniechęceniami. Dominikanin, porównując cnoty męstwa i cierpliwości, stwierdza, że ta pierwsza pozwala znosić największe, ale krótkotrwałe niedogodności, druga natomiast daje wytrwałość w cierpieniach mniejszych, ale długotrwałych lub często powracających. Drugą w grupie męstwa cnotą jest długomyślność. Polega na tym, by nie dać się opanować przez smutek i zniechęcenie. Ma ono jednak inny niż przy cierpliwości charakter, bardziej negatywny, dotyczy dobra, na które bardzo długo trzeba czekać. Zdaniem Woronieckiego nikt nie potrzebuje jej bardziej niż ci, którzy wychowują innych (Woroniecki, 1930). Wychowanie bowiem jest procesem długotrwałym, na którego rezultaty niejednokrotnie należy bardzo długo czekać. Inną cnotą pokrewną męstwu jest wielkoduszność, nazywana przez niego zdrową ambicją. Jej przedmiotem jest dobro trudne do zdobycia, które rodzi w człowieku dwa podstawowe uczucia: otuchę i zniechęcenie. Dominikanin konstatuje, że w sytuacji, w której jakiś przedmiot człowieka pociąga, a trudności odpychają, nieodzowne są dwie cnoty: pokora, należąca do grupy umiarkowania, która hamuje ludzkie nadmierne pożądanie dobra, oraz wielkoduszność, wpisująca się w męstwo, która podtrzymuje wysiłki w przezwyciężaniu trudności. Pokora i wielkoduszność ściśle się ze sobą wiążą i uzupełniają.

Nawiązując do myśli Arystotelesa, który wyróżnia dwa stopnie wielkoduszności: filotimię - miłość czci, dostępną dla wszystkich ludzi, oraz megalopsychię - wielkoduszność, przeznaczoną dla osób zajmujących stanowiska w społeczeństwie, dominikanin stwierdza, że wszyscy powinni dbać o cześć ze strony otoczenia i starać się tak postępować, by na nią zasłużyć. Człowiek nie może wyrzekać się prawdziwej wielkości, ponieważ jest ona następstwem osobistej godności i czci okazywanej rozumnej naturze ludzkiej, otrzymanej od Boga. Wielkoduszność ma przyczynić się do rozumnego dążenia do wielkości i dbania o cześć należną człowiekowi.

Wśród cnót pokrewnych męstwu dominikanin wyróżnia również stałość i wytrwałość, które są związane ze składnikiem roztropności zwanym 
stałością woli. Przedmiotem cnoty stałości są trudności, które pojawiają się na drodze do realizacji celu. Oznacza ona nastrój duszy zapewniający nieustępliwość i nieugiętość. Wytrwałość dotyczy okoliczności czasu, która może utrudniać obstawanie przy realizacji zamierzenia. Gdy brakuje wytrwałości, męstwo jest zagrożone. Ostatnią z cnót pokrewnych męstwu jest święty gniew, nazywany przez o. Woronieckiego sprawnością dodatnią, której przedmiotem jest troska i zabieganie o chwałę Bożą. Siła gniewliwa, wpisana w naturę ludzką, winna być niekiedy wprowadzana w czyn przez rozum i wolę, aby zwalczać przeszkody, które pojawiają się na drodze do wielkich celów życiowych (Woroniecki, 1983).

Popadnięcie w pewien nadmiar lub niedomiar cnoty męstwa i cnót jej pokrewnych wskazują na wady im przeciwstawne. Najważniejszą z nich jest próżność, mająca swe źródło w miłości własnej. Człowiek próżny zabiega o rozgłos i sławę, a dla osiągnięcia popularności używa niegodziwych środków. Z próżnością wiążą się samochwalstwo i kłamliwość, które mogą prowadzić do hipokryzji. Cnocie męstwa zagraża marzycielstwo, które zatrzymuje człowieka $\mathrm{w}$ realizacji obranego celu. Wadami przeciwstawnymi przedmiotowej cnocie kardynalnej są również tchórzostwo i zuchwalstwo. To pierwsze oznacza stałą skłonność do poddawania się bojaźni, świadczącą o niepanowaniu nad uczuciem strachu, natomiast drugie jest nadużyciem odwagi i fałszywym nadmiarem męstwa, jego zwyrodnieniem. Zuchwalstwo jest szczególnie niebezpieczne, ponieważ człowiek cechujący się tą wadą, uchodząc za odważnego, oszukuje siebie samego i środowisko. W rzeczywistości bezcelowo naraża się na niebezpieczeństwo (Woroniecki, 1938). Wadą przeciwstawną męstwu, obserwowaną często we współczesnym świecie, jest małoduszność. Oznacza ona skłonność do sądzenia o sobie gorzej niż na to się zasługuje oraz uważanie siebie za niezdolnego do realizacji celów, które realnie można by spełnić. Dominikanin konstatuje, że źródłem tej wady są lenistwo, czyli niechęć do wysiłku, by wydobyć z siebie ukryte zdolności i rozwinąć je przez pracę, oraz pycha. Towarzyszy jej obawa przed odpowiedzialnością oraz tchórzostwo. Małoduszność jest wadą niezwykle szkodliwą dla życia społecznego. W kształtowaniu cnoty męstwa przeszkadzają również zarozumiałość, która ma swe źródło w rozumie, w niedostatecznym poznaniu siebie, oraz wygórowana ambicja, mająca źródło w woli, w dążeniu do zaszczytów i honorów. Człowiek zbyt ambitny, w przeciwieństwie do człowieka małodusznego, nie unika pracy, jednak głównym motywem jego postępowania jest zdobycie czci i uznania, szczególnie osób wpływowych. Szkodliwy jest także upór, czyli nadmiar, ale nie w wytrwałości 
przy dobru, ale przy złu lub dobru niekoniecznym, by warto było przy nim obstawać. Przybiera często pozory stałości, niezmienności przekonań lub bezkompromisowości, co czyni go jeszcze bardziej niebezpiecznym.

Świadomość wad przeciwstawnych cnocie męstwa może pomóc w jej kształtowaniu. Podobnie jak w przypadku innych cnót, również przy prowadzeniu wychowanka do męstwa istotna jest metoda przykładu. Woroniecki zaleca ponadto, aby dać zrozumieć dziecku, że strach nie jest niczym złym, bo kieruje uwagę na niebezpieczeństwo. Należy jednak wskazać, czego należy się bać, a co nie powinno budzić strachu. Męstwo ćwiczy się poprzez ugruntowanie zdrowej odwagi, ale również w kształtowaniu usposobienia niecofania się w obliczu niebezpieczeństw, gdy chodzi o wielkie sprawy czy wartości moralne. Szczególnie współcześnie, w dobie szybkich zmian i równie szybkich reakcji na ludzkie działanie, konieczne wydaje się wychowanie do cnoty cierpliwości i długomyślności. Dominikanin przestrzega przed zbytnim rozczulaniem się nad cierpieniem dzieci i młodzieży, radząc podtrzymywanie na duchu z jednoczesnym żądaniem niepoddawania się zniechęceniu. Należy uczyć wychowanków odpowiedzialności, a szczególnie gotowości do podejmowania wyzwań, wytrwałości oraz stałości w ich realizacji.

\section{Umiarkowanie - doskonaleniem uczuć pożądliwych}

Dzięki cnocie umiarkowania możliwe jest porządkowanie tzw. uczuć pożądania. W dziedzinie zmysłowej człowiek odczuwa najsilniejsze popędy, gdyż są one mu najbliższe i najmocniej go pociągają. $Z$ tego powodu miarkowanie ich jest bardzo trudne do ujęcia rozumem. Ojciec Woroniecki, nawiązując do rozważań Arystotelesa, wskazuje na dwojaki stosunek pożądań zmysłowych do rozumu i woli. Przypadek, gdy dziedzina zmysłów nie jest wewnętrznie opanowana przez cnotę, a tylko z zewnątrz utrzymywana przez silną wolę, określa się jako powściągliwość. Cnota umiarkowania polega na przeniknięciu impulsów rozumu i woli do uczuć zmysłowych i wytworzenie w nich stałych usposobień do poddania się ich kierownictwu (Woroniecki, 1983). Umiarkowanie, podobnie jak inne cnoty kardynale, jest cnotą złożoną. Jego źródłem jest dziedzina pożądania. Dominikanin wymienia sześć uczuć pożądanych, pożądliwych, tj. upodobanie i jego brak, pożądanie i wstręt, radość i smutek. Oprócz tych uczuć cnota grupy umiarkowania składa się z dwóch bardziej złożonych składników: godności osobistej i wstydliwości. Człowiek jako istota rozumna, zdolna do kierowania się wyższymi motywami niż tylko zaspokajanie własnych przyjemności, posiada wrodzone poczucie godności. Wstydliwość, składająca się z odrazy i strachu, obejmuje zewnętrzny wstręt do zła i wszystkiego, co człowieka może „obniżyć” 
i zanieczyścić, oraz obawę przed zniesławieniem. Wrodzona skłonność do wstydliwości przejawia się głównie w sferze zmysłowej. Dominikanin stwierdza, że przez nadmierne oddawanie się zmysłom, człowiek wyrzeka się swojej godności jako istoty rozumnej, a potem odczuwa wstyd. Przestrzega jednak przed skrajnością zbytniego wyolbrzymiania wstydliwości, która może skutkować niezdrową lękliwością wobec przejawów życia zmysłowego (Woroniecki, 1983). Cnota umiarkowania dotyczy dwóch obszarów życia człowieka: odżywiania, czyli panowania nad smakiem, i należą tu cnoty wstrzemięźliwości i trzeźwości, oraz stosunków płciowych, czyli panowania nad dotykiem, i należy tu cnota czystości. Porównując dziedzinę odżywiania i dziedzinę stosunków płciowych, warto zaznaczyć, że chociaż pożądanie jedzenia i picia jest częstsze i silniejsze, to jednak pożądanie płciowe pociąga za sobą skutki społeczne, gdyż zazwyczaj angażuje drugą osobę.

Wśród cnót pokrewnych umiarkowaniu szczególne znaczenie przypisuje dominikanin łagodności, cichości i wyrozumiałości. Zadaniem tej pierwszej jest takie panowanie nad gniewem, aby nie uprzedzał działania rozumu i woli. Spokrewniona z łagodnością jest cichość, czyli umiar w mowie. Zadaniem wyrozumiałości, czyli łaskawości jest miarkowanie porywów gniewu i pożądania odwetu. Silnie oddziałuje na ludzkie zmysły cnota pokory, choć należy do dziedziny umysłowej. Jej zadanie polega na nadaniu umiaru w pożądaniu wyniesienia się ponad innych. Pierwszym i najważniejszym aktem pokory jest pochwała, czyli uznanie w czymś wyższości drugiego człowieka, najtrudniejszym - przeproszenie. Kolejnymi cnotami bliskimi umiarkowaniu są skromność, która dotyczy głównie zachowania umiaru w zewnętrznym zachowaniu człowieka, oraz umiejętność odpoczywania i godziwego używania rozrywek. Zarówno w dziedzinie ciała, jak i ducha potrzeba odpoczynku, dzięki któremu człowiek odzyskuje spokój i zadowolenie. Cnota umiaru ma chronić przed utratą panowania nad sobą czy nieprzestrzeganiem reguł obowiązujących w określonej dziedzinie rozrywek (Woroniecki, 1983).

Wady przeciwstawne cnocie umiarkowania bliższe są nadmiarowi, czyli nieumiarkowanemu pożądaniu niż niedomiarowi. Najważniejszą z nich jest nieumiarkowanie, oznaczające stałe usposobienie woli i uczuć, aby zaspokoić każde pożądanie zmysłowe. Może ono dotyczyć różnych dziedzin życia. Dominikanin wymienia między innymi: łakomstwo, alkoholizm, narkomanię, nieczystość, rozwiązłość, obraźliwość, złośliwość, mściwość, pychę, ciekawość. Do wad im pokrewnych zalicza między innymi zbytnią wesołość, gadulstwo, niedbałość o odżywianie, nieczystość, podejrzliwość, obojętność, uniżoność, niedbałość o wygląd zewnętrzny, manię pracy, manię rekordów. 
Świadomość wad przeciwstawnych cnocie umiarkowania może pomóc w jej zdobyciu, co, jak zauważa o. Woroniecki, jest szczególnie trudne w społeczeństwie opanowanym konsumpcjonizmem i utylitaryzmem. Uporządkowanie dziedziny doznań zmysłowych jest jednak możliwe i należy o nie zabiegać. W wychowaniu do umiarkowania ważna jest troska o opanowywanie popędów. Człowiek powinien stwarzać sam okazje do odmawiania sobie czegoś. W wychowaniu do czystości nie chodzi o pruderię, ale stopniowe dochodzenie młodego człowieka do świadomości płciowej, szczególnie należy dbać o dobry przykład otoczenia. Zadanie to wydaje się współcześnie niezwykle trudne, dlatego tym bardziej powinno się zabiegać o jego realizację. Wychowanie do panowania nad gniewem i złością proponuje dominikanin prowadzić przez przykład wychowawcy - człowieka łagodnego, opanowanego i wyrozumiałego. Niezbędna w nabyciu cnoty umiarkowania jest pokora. Drogą do jej zdobycia jest od strony pozytywnej pochwała, prośba i podziękowanie, a od strony negatywnej - przeproszenie. Należy już od najmłodszych lat wdrażać dzieci do tych aktów. Niemniej ważne jest wychowanie do pilności, skromności oraz nabycia umiejętności odpoczywania i godziwego używania rozrywek.

Umiarkowanie i cnoty mu pokrewne wprowadzają umiar i ład w wielu dziedzinach ludzkiego życia. Powstrzymanie się od przyjemności i dążeń prowadzi do regulowania całego życia człowieka.

Sprawności - cnoty możliwe są do ukształtowania jedynie wówczas, gdy przyrodzone wysiłki człowieka zostaną wsparte przez nadprzyrodzoną łaskę Boga. Osiągnięcie cnót kardynalnych nie jest możliwe bez cnót teologalnych: wiary, nadziei i miłości, które łączą człowieka z Chrystusem (Woroniecki, 1938).

\section{CNOTY TEOLOGALNE}

Cnoty teologalne, zwane wlanymi lub boskimi, dodają do całokształtu sprawności kardynalnych czynnik nadprzyrodzony, który oczyszcza, rozwija i podnosi na wyższy poziom to, co jest twórcze w dziedzinie przyrodzonej. Jeśli zabraknie cnót teologalnych, celem człowieka nie będzie Bóg, ale dobra doczesne, przez co człowiek nie zrealizuje swojego potencjału i nie osiągnie doskonałości. Przedmiotowe cnoty powodują stałe usposobienie władz ludzkich, rozumu i woli, względem Boga. 
Wiara wspomaga rozum człowieka, oświeca go poprzez poznanie nowych prawd. Pobudza też wolę, sprawiając, że uznaje on za prawdę wszystko to, co zostało podane mu do wierzenia przez Objawienie, i postrzega doczesne zobowiązania przez pryzmat życia wiecznego. Wiara poszerza horyzonty życia duchowego, pozwala przekraczać przyrodzone cele i zainteresowania (Woroniecki, 1923; Horowski, 2007).

Nadzieja wytwarza nastawienie ufności względem Boga, które pomaga w przezwyciężaniu trudności, jakie oddalają człowieka od ostatecznego celu jego życia. Udoskonalając wolę, rozwija, utrwala i podnosi do poziomu nadprzyrodzonego pragnienie pełni szczęścia w Bogu.

Wśród cnót teologalnych na pierwsze miejsce wysuwa się miłość, która łączy człowieka z Bogiem. Ukierunkowuje wolę ludzką na Stwórcę jako dobro najwyższe, z którym człowiek winien być połączony wewnętrznym upodobaniem, życzliwością i przyjaźnią. Wówczas człowiek zapomina o sobie, troszcząc się o sprawy osoby kochanej (Woroniecki, 1995).

Cnoty wlane są skutkiem działania Boga w człowieku, nie przeciwstawiają się jednak przyrodzonemu działaniu ludzkiemu, przekraczają je i doskonalą. Cnota wlana oddziałuje wyłącznie na fundamencie rozwiniętej sprawności nabytej, powodując jej wzrost (Woroniecki, 1938). I tak udoskonalony przez wiarę rozum może osiągnąć właściwą cnotę roztropności, dzięki której człowiek będzie mógł zrealizować powołanie do świętości. Analogicznie udoskonalona przez miłość i nadzieję wola przyczynia się do zdobycia prawdziwej cnoty sprawiedliwości. Cnoty teologalne nie niszczą natury ludzkiej, lecz ją udoskonalają, ich wzrost jest wpisany w integralny rozwój człowieka. Cnoty kardynale i teologalne należy rozwijać równocześnie, powinny stanowić spójną całość, nadającą postępowaniu człowieka cechę stałości, umiaru, jednolitości moralnej, którą o. Woroniecki nazywa charakterem chrześcijanina (Woroniecki, 1995).

Człowiek w celu pełnej realizacji swojej potencjalności winien sięgać po wszystkie naturalne środki rozwoju. Nie są one jednak w stanie zapewnić mu pełnego rozwoju bez zjednoczenia z Bogiem. Dominikanin, poza istotną rolą cnót wlanych w tym obszarze, wskazuje na cnotę pobożności, która jest według niego pierwszą spośród cnót moralnych. Równocześnie jest ona integralną częścią cnoty kardynalnej sprawiedliwości, oznacza bowiem sprawiedliwość względem Boga. 


\section{Pobożność - usprawnieniem woli i zmysłów do oddawania czci należ- nej Bogu}

Pobożność, nazywana również przez Woronieckiego religijnością, jest pierwszą spośród cnót moralnych „mających za zadanie usprawnić nas do należytego posługiwania się nimi wedle wymagań prawa moralnego" (Woroniecki, 1986, s. 273). Pobożność nie jest czwartą cnotą teologiczną, bo jej przedmiotem nie jest Bóg, za jej pośrednictwem jednak człowiek oddaje Bogu cześć, wdzięczność, żal za wykroczenia przeciw Jego woli. Cnota ta jest ściśle związana $\mathrm{z}$ wiarą. Człowiek niewierzący nie jest bowiem w stanie zrozumieć życia religijnego. Wyznacznikami pobożności chrześcijańskiej są codzienny pacierz, święcenie dnia świętego, przyjmowanie sakramentów oraz cześć i posłuszeństwo względem Kościoła i jego pasterzy. Ugruntowanie cnoty religijności jest możliwe dzięki regularności w oddawaniu czci Bogu w codziennej modlitwie. Równie ważne jest święcenie dnia świętego, niedzieli i świąt obowiązujących w Kościele. Chodzi tu o dwa rodzaje obowiązków. Pierwszy z nich, mający charakter pozytywny, polega na uczestnictwie we mszy św., drugi - negatywny nakazuje powstrzymanie się od wykonywania pracy. Ojciec Jacek Woroniecki zauważa, że dzień świąteczny w czasach mu współczesnych coraz bardziej traci swój religijny charakter, stając się jedynie dniem odpoczynku i rozrywki (Woroniecki, 1986). Wydaje się, że obecnie dni świąteczne mają takie właśnie znaczenie dla większości przedstawicieli nowoczesnych społeczeństw. Kolejnymi składnikami cnoty pobożności są przyjmowanie sakramentów oraz cześć i posłuszeństwo względem Kościoła i jego pasterzy. Te ostatnie powinny być przeniknięte duchem wiary w boskie pochodzenie Kościoła i jego związek z Chrystusem. Posłuszeństwo względem Kościoła ma swoje źródło w podporządkowaniu wierzących dobru wspólnemu. Woroniecki podkreśla, że dzięki temu posłuszeństwu człowiek może osiągnąć pełnię rozwoju własnej osobowości, gdyż ma ono wartość nadprzyrodzoną. Cześć winna być wyrażana nie tylko wewnętrznie w gorliwości i modlitwie, ale również zewnętrznie, między innymi poprzez post czy ofiarę. Gorliwość, czyli gotowość, pilność, staranność i dbałość, zdaniem o. Woronieckiego powinna przejawiać się w cnocie pobożności, ale również w każdej innej cnocie moralnej, towarzysząc wszystkim czynnościom ludzkim.

Cnotą pokrewną pobożności jest cnota pokuty. Jej zadaniem jest utrzymanie stałego usposobienia i gotowości do przyjmowania wszystkiego, co przykre w duchu zadośćuczynienia i wynagrodzenia czci Bożej znieważonej popełnionym grzechem. Oznacza stałą chęć do zaparcia się siebie, umartwień 
i cierpień, które są konieczne do prowadzenia chrześcijańskiego życia. Aktami cnoty pokuty są skrucha, zadośćuczynienie i umartwienie (Woroniecki, 1986; Kempys, 2005).

Nad cnotą pobożności należy pracować od najmłodszych lat. Nieodzowny jest tu dobry przykład otoczenia, w którym wychowanek wzrasta. Ojciec Woroniecki zaznacza, że jedynie stałe impulsy regularnie otrzymywane z zewnątrz mogą przyczynić się do powstania trwałego usposobienia do podobnych czynności religijnych. Ponadto ważna jest zgodność między pobożnością a całokształtem postępowania moralnego. Dlatego, jak podkreśla współczesny pedagog obszaru niemieckojęzycznego Wolfgang Brezinka, rodzice mogą skutecznie kształtować cnoty, również cnotę religijności, w zasadzie tylko wtedy, gdy przyłączą się do kręgu przyjaciół lub większej wspólnoty osób podobnie myślących i postępujących, gdy zadbają o otoczenie, w którym ich dziecko będzie miało szansę otrzymać podobne wzorce i punkty orientacyjne (Brezinka, 2003).

Przy wychowywaniu do pobożności warto być świadomym wad przeciwnych tej cnocie, wśród których o. Woroniecki wyodrębnia zabobonność, niedbalstwo w służbie Bożej i bezbożność. Jednym z przejawów zabobonności jest przesądność, oznaczająca wiarę w przesądy dotyczące dni, liczb lub zdarzeń feralnych (Woroniecki, 1986). We współczesnych społeczeństwach, określanych często jako społeczeństwa wiedzy, wciąż obecna jest ta wada, również w środowiskach chrześcijańskich. Woroniecki podkreśla, że przesądy mają w sobie coś grzesznego i sieją zgorszenie, gdyż są związane z niedomaganiem wiary (Woroniecki, 1986).

Cnota pobożności jest swoistym łącznikiem między cnotami kardynalnymi i teologalnymi. Jej uformowanie znacznie ułatwia osiągnięcie pełni rozwoju przez człowieka.

\section{PODSUMOWANIE}

Wydaje się, że oparcie wychowania na założeniach aksjologicznych, włącznie z aretologicznymi, jest gwarantem osiągnięcia pełni rozwoju przez wychowanka, a przynajmniej maksymalnego do niego zbliżenia. Analiza założeń aretologicznych koncepcji o. Woronieckiego, sięgającej do filozofii arystotelesowsko-tomistycznej, która wskazuje na potencjalność wszystkich funkcji życiowych człowieka, unaocznia argumenty dotyczące potrzeby ich usprawniania, aby dojść do biegłego wykonywania właściwych, odpowiadających 
tym funkcjom czynności. Rozwój poszczególnych sprawności - cnót umożliwia zaktualizowanie potencjalności człowieka. Cnoty, które omawia o. Woroniecki, są aktualne dla współczesnej sytuacji społeczno-kulturowej, a ich uformowanie niewątpliwie może przyczynić się do pełni rozwoju współczesnego człowieka.

Oparcie wychowania na założeniach aretologicznych powinno odwoływać się do problematyki aksjologicznej, która zakłada nie tylko poznanie wartości, ale przede wszystkim uwzględnia moralną kondycję bytu ludzkiego. Zapoznawanie wychowanka $\mathrm{z}$ cnotami i wartościami niewątpliwie przyczynia się do zbudowania wiedzy o nich, ale nie przekłada się bezpośrednio na ich zinterioryzowanie, aby kierowały jego życiem. Wychowanie do wartości, czy w wartościach, wpływa na życiowe postawy człowieka, nie usprawnia jednak poszczególnych, istniejących w nim władz rozumu, woli, zmysłów i uczuć. W tym wymiarze niezbędna jest systematyczna praca nad sobą, aby doskonalić się w poszczególnych sprawnościach - cnotach. Nie może być to związane z nabywaniem nawyków bez udziału czynnika świadomości.

Odwoływanie się do założeń aretologicznych w konstruowaniu programów wychowawczych może przyczynić się do pełniejszego opracowania pedagogiki aksjologicznej z uwzględnieniem moralnej kondycji podmiotu.

Można pokusić się o uwagę, że pedagogika wybitnego uczonego i humanisty o. Woronieckiego ze swoimi aretologicznymi podstawami wciąż stanowi cenną wychowawczą inspirację i jako taka domaga się, by odczytać ją na nowo.

\section{BIBLIOGRAFIA}

BrezinKA, W. (2003). Erziehung und Pädagogik im Kulturwandel. München: Ernst Reinhardt Verlag. BREZINKA, W. (1981). Grundbegriffe der Erziehungswissenschaft. München: Ernst Reinhardt Verlag.

GaŁkowski, S. (1998). Ku dobru. Aktualność filozofii wychowania Jacka Woronieckiego. Rzeszów: Wydawnictwo Wyższej Szkoły Pedagogicznej.

Horowski, J. (2007). Paedagogia perennis w dobie postmodernizmu. Wychowawcze koncepcje o. Jacka Woronieckiego a kultura przełomu XX i XXI wieku. Toruń: Europejskie Centrum Edukacyjne.

Kempys, M.J. (2005). Rola cnót moralnych $w$ dażeniu do pelni czlowieczeństwa $w$ świetle pism o. Jacka Woronieckiego. Kraków: Wydawnictwo Naukowe PAT.

Kunowski, S. (2001). Podstawy współczesnej pedagogiki. Warszawa: Wydawnictwo Salezjańskie.

Nowak, M., Magier, P., Szewczak, I. (2010). Wprowadzenie. W: M. Nowak, P. Magier, I. SzEWCZAK (red.), Antropologiczna pedagogika ogólna (s. 7-15). Lublin: Gaudium-Wydawnictwo KUL.

ŚLEZIŃSKI, K. (2016). Aretologiczne podstawy pedagogiki. Kraków-Cieszyn: Wydawnictwo Scriptum. 
Woroniecki, J. (1938). Cnota kardynalna męstwa. Jej istotne cechy, niedomagania i wychowanie. Szkoła Chrystusowa, 9, 233-243.

Woroniecki, J. (1930). Długomyślność jako właściwa cnota wychowawcy. Szkoła Chrystuso$w a, 4,178-195$.

WoronieCKI, J. (1995). Katolicka etyka wychowawcza, t. 1. Lublin: Redakcja Wydawnictw KUL.

WoronieCKI, J. (1983). Katolicka etyka wychowawcza, t. 2. Lublin: Redakcja Wydawnictw KUL.

WoronieCKI, J. (1923). Studium nad kardynalną cnotą roztropności. Kwartalnik Teologiczny Wileński, 1-2, 226-247.

Woroniecki, J. (1961). Wychowanie człowieka. Pisma wybrane. Wyboru dokonał W. Szymański. Opracował J. Kołątaj. Kraków: Wydawnictwo Znak.

\section{W TROSCE O ARETOLOGICZNE PODSTAWY WYCHOWANIA. WOKÓŁ KONCEPCJI O. JACKA WORONIECKIEGO}

\section{STRESZCZENIE}

Artykuł podejmuje problematykę aretologicznych podstaw wychowania. Podjęto w nim próbę odpowiedzi na pytanie o zasadność odwoływania się w wychowaniu do teorii cnót, zaproponowanej przez o. Jacka Woronieckiego. Przedstawiono argumenty potwierdzające potrzebę odwoływania się w wychowaniu do tej teorii. Wykazano, że zaproponowane przez o. Jacka Woronieckiego sprawności: roztropność, sprawiedliwość, męstwo, umiarkowanie oraz wiara, nadzieja, miłość, a także pobożność mogą stanowić aktualne cele wychowania. Ich realizacja przyczynia się do aktualizacji potencjalności wychowanka i może stanowić odpowiedź na obserwowany współcześnie kryzys wychowania. Podjęto za o. Jackiem Woronieckim krytykę stanowiska intelektualizmu moralnego, podkreślając, że uwzględnienie w wychowaniu do cnót nie tylko rozumu, ale i woli jest konieczne do nabycia samych cnót.

Słowa kluczowe: aretologia; wychowanie; cnoty kardynalne i teologalne; o. Jacek Woroniecki.

IN THE INTEREST OF THE ARETHOLOGICAL BASIS OF UPBRINGING

\section{SUMMARY}

The article presents the issue of the aretological basis of upbringing. An attempt has been made to answer the question about the legitimacy of referring to the virtue theory in upbringing proposed by Father Jacek Woroniecki. Arguments confirming the need to refer to the virtue theory in upbringing have been presented. It has been shown that the efficiency proposed by Fr. Jacek Woroniecki: prudence, justice, valour, moderation and faith, hope, love as well as piety can constitute current goals of education. Their realization contributes to updating the potential of the pupil and may be a response to the crisis of education observed today. Father Jacek Woroniecki criticized the approach of moral intellectualism, emphasizing that involving not only reason but also will in the upbringing to the virtues is necessary for the pupil to acquire the virtues.

Key words: aretology; upbringing; cardinal and theological virtues; Fr. Jacek Woroniecki. 